\title{
HUBUNGAN PENGETAHUAN DAN SIKAP DENGAN TINDAKAN PERSONAL HYGIENE SAAT MENSTRUASI PADA REMAJA PUTRI
}

\author{
Husni, Pauzan Efendi \\ Politeknik Kesehatan Kementerian Kesehatan Bengkulu, Jurusan Keperawatan, \\ Jalan Indragiri Nomor 03 Padang Harapan Kota Bengkulu \\ jmkbengkulu@gmail.com
}

\begin{abstract}
Abstrac : One of the effects is not maintaining hygiene during menstruation is able to hit kankes Rahim neck (cervical). Based on data from the World Health Organization (WHO), cervical cancer is the second most cancer in women aged 15-45 years after breast cancer. No less than 500,000 new cases with 280,000 patient deaths occur each year worldwide. Indonesia was ranked first by the victims died at least 555 women per day and 200,000 women annually. This study aims to determine the correlation between knowledge and attitude towards personal hygiene during menstruation action at SMAN 2 Bengkulu City. This research is descriptive analytic. The number of respondents 84 people with a sampling technique that stratified random sampling. Presentation of data is done by using a frequency distribution table. The collection of data taken using a questionnaire. The data were analyzed using univariate and bivariate analysis with Chi-Square.The results showed that the respondents are classified as good knowledge of (54.8\%), attitude unfavorabel or does not support (53.6\%), and the biggest acts (52.4\%) is good. From the bivariate analysis were found no correlation between knowledge against acts of personal hygiene during menstruation $(\mathrm{p}=$ 0.794), and no relation attitude towards personal hygiene actions during menstruation ( $\mathrm{p}=$ 0.975).Required role of schools, educators, parents to be more proactive in enhancing knowledge and useful information about the process of menstruation and how to maintain hygiene during menstruation.
\end{abstract}

Keyword: Knowledge, Attitude and measures

\begin{abstract}
Abstrak: Salah satu dampak tidak menjaga higenitas pada saat menstruasi adalah dapat terkena kankes leher Rahim (serviks). Berdasarkan data dari badan kesehatan Dunia (WHO), kanker serviks merupakan kanker nomor dua terbanyak pada perempuan berusia 15-45 tahun setelah kanker payudara. Tidak kurang dari 500.000 kasus baru dengan kematian 280.000 penderita terjadi setiap tahun diseluruh dunia. Indonesia berada pada peringkat pertama dengan korban meninggal dunia sedikitnya 555 wanita perharinya dan 200.000 wanita pertahunnya. Penelitian ini bertujuan untuk mengetahui hubungan pengetahuan dan sikap terhadap tindakan personal hygiene saat menstruasi di SMA Negeri 2 Kota Bengkulu. Penelitian ini bersifat deskriptif analitik. Jumlah responden 84 orang dengan teknik pengambilan sampel yaitu stratified random sampling. Penyajian data dilakukan dengan menggunakan tabel distribusi frekuensi. Pengumpulan data diambil dengan menggunakan kuesioner. Data yang terkumpul dianalisis dengan menggunakan analisis univariat dan analisis bivariat dengan Chi-Square. Hasil penelitian menunjukkan bahwa pengetahuan responden tergolong baik sebesar (54.8\%), sikap unfavorabel atau tidak mendukung (53.6\%), dan tindakan terbesar (52.4\%) yaitu baik. Dari analisa bivariat di temukan tidak ada hubungan pengetahuan terhadap tindakan personal hygiene saat menstruasi $(\mathrm{p}=0,794)$, dan tidak ada hubungan sikap terhadap tindakan personal hygiene saat menstruasi $(\mathrm{p}=0,975)$. Diperlukan peran sekolah, pendidik, orang tua untuk lebih proaktif dalam meningkatkan pengetahuan dan informasi yang berguna tentang proses terjadinya haid dan cara menjaga kebersihan selama menstruasi.
\end{abstract}

Keyword: Pengetahuan, Sikap dan Tidakan 
Hasil penelitian yang telah dilakukan menyatakan bahwa kurangnya perilaku higienis saat menstruasi dapat menyebabkan berbagai penyakit misalnya kanker rahim. Berdasarkan data dari badan kesehatan Dunia (WHO), kanker serviks merupakan kanker nomor dua terbanyak pada perempuan berusia 15-45 tahun setelah kanker payudara. Tidak kurang dari 500.000 kasus baru dengan kematian 280.000 penderita terjadi setiap tahun diseluruh dunia. Bisa dikatakan, setiap dua menit seorang perempuan meninggal akibat kanker serviks. Di Wilayah Asia Pasifik dan Timur Tengah ada 1,3 Milyar perempuan berusia 13 tahun ke atas yang beresiko terkena kanker serviks. WHO memperkirakan ada lebih dari 265.000 kasus kanker serviks dengan kematian 140.000 penderita setiap tahun di wilayah ini. Menurut data Globocan 2002, terdapat lebih dari 40.000 kasus baru kanker serviks dengan sekitar 22.000 kematian karenanya pada wanita di Asia Tenggara (Progestian, 2009).

Indonesia berada pada peringkat pertama untuk kasus wanita penderita kanker mulut rahim (serviks) sedunia, sedangkan data dari Yayasan Kanker Indonesia, bahwa penyakit penyakit kanker leher rahim (serviks) mengakibatkan korban meninggal dunia sedikitnya 555 wanita perharinya dan 200.000 wanita pertahunnya. Menurut beberapa penelitian menyebutkan bahwa kanker ini disebabkan oleh virus Human Papilloma Virus (HPV) yang muncul, antara lain karena perilaku sering berganti-ganti pasangan seks dan perilaku yang tidak higienis pada saat menstruasi. Virus ini hidup di daerah yang lembab, persisnya dalam cairan vagina yang diidap oleh penderita keputihan (leukore). Jika keputihan ini tidak segera membaik, virus ini bisa memunculkan kanker rahim. Biasanya keadaan ini ditandai dengan banyaknya cairan keputihan yang disertai bau tidak sedap dan perdarahan yang keluar dari vagina. Tapi ada kalanya kanker yang muncul itu tidak memberikan gejala-gejala sakit seperti itu. Ditemukan penyebab utama kanker mulut rahim di Indonesia adalah pembalut berkualitas buruk (Progestian, 2009).Badan kesehatan dunia (WHO) memperkirakan bah- wa tahun 2025 Indonesia akan mengalami peningkatan jumlah warga lansia sebesar $11,4 \%$, yang merupakan peningkatan tertinggi dunia. Perserikatan Bangsa-Bangsa memperkirakan bahwa di tahun 2025 jumlah warga lansia di Indonesia akan mencapai \pm 60 juta jiwa. Indonesia berada pada peringkat ke-4 untuk jumlah penduduk lansia terbanyak setelah Cina, India, dan Amerika serikat. Meningkatnya jumlah penduduk usia lanjut (lansia) menimbulkan masalah terutama dari segi kesehatan dan kesejahteraan lansia (WHO, 2009).

Pendapat Fishbein dan Azjen (Azwar, 2003) yang menyebutkan bahwa pengetahuan seseorang tentang sesuatu hal akan mempengaruhi sikapnya. Sikap tersebut positif maupun negatif tergantung dari pemahaman individu tentang suatu hal tersebut, sehingga sikap ini selanjutnya akan mendorong individu melakukan tindakan tertentu pada saat dibutuhkan, tetapi kalau sikapnya negatif, justru akan menghindari untuk melakukan perilaku tersebut (Indriastuti, 2009).

Menurut Morgan (Utami, 2003) orang tua, seperti ayah, kakak atau saudara perempuan, khususnya ibu, diharapkan mampu memberikan informasi yang tepat dan benar tentang apakah menstruasi itu. Jika mengetahui informasi yang benar tentang menstruasi maka anak remaja perempuan akan merasa siap ketika mendapatkan menstruasi pertama kali. Seperti dikatakan oleh Astuti (2003) bahwa pendidikan seputar menstruasi mempengaruhi kesiapan anak perempuan menjelang remaja untuk menghadapi menarche. Oleh karena itu, pendidikan seputar menstruasi disarankan untuk diterapkan bagi anak remaja perempuan yang belum mengalami menstruasi sebagai salah satu cara untuk menumbuhkan kesiapan menghadapi menarche. Selanjutnya jika individu tahu hal apa saja yang harus dilakukan pada saat mengalami kondisi yang sama, misalnya bagaimana cara mengatasi keluarnya darah menstruasi yang dapat terjadi sewaktu-waktu, bagaimana cara memakai dan mencuci pembalut, serta bagaimana cara perawatan diri pada saat menstruasi, maka dapat diharapkan 
individu berperilaku higienis ketika mengalami menstruasi (Indriastuti, 2009).

Berdasarkan survey pendahuluan oleh peneliti, sebagian besar murid SMA Negeri 2 Bengkulu berjenis kelamin perempuan, dimana setiap perempuan pasti mengalami menstruasi setiap bulannya. Selain itu frekuensi proses belajar mengajar hingga ektrakurikuler berlangsung relatif lama dari pagi hari hingga sore hari, sehingga sangat berpengaruh terhadap tindakan personal hygiene remaja putri pada saat menstruasi. Saat dilakukan wawancara langsung kepada remaja putri pada tanggal 19 Oktober 2013 di SMA Negeri 2 Kota Bengkulu tentang personal hygiene saat menstruasi didapatkan dari 10 responden 6 orang mengatakan belum mengerti tentang personal hygiene saat menstruasi dan 4 orang merasakan gatal-gatal pada daerah kewanitaan pada saat menstruasi. Disamping itu asumsi peneliti, murid SMA Negeri 2 Bengkulu memiliki banyak sumber informasi dimana hal tersebut akan mempengaruhi pembentukan pengetahuan dan sikap remaja putri di SMA Negeri 2 Bengkulu mengenai pemilihan pembalut.

Penelitian ini bertujuan untuk mengetahui hubungan pengetahuan dan sikap terhadap tindakan personal hygiene saat menstruasi di SMA Negeri 2 Kota Bengkulu

\section{BAHAN DAN CARA KERJA}

Jenis penelitian ini adalah Deskriptif Analitik dengan menggunakan rancangan penelitian Cross Sectional dimana peneliti mengukur variabel independen dan dependen secara bersamaan dan hasil yang diperoleh menggambarkan kondisi yang terjadi saat penelitian dilaksanakan. Populasi dalam penelitian ini adalah semua remaja putri di SMA Negeri 2 Kota Bengkulu. Sampel yang berjumlah 84 orang diambil dengan menggunakan metode stratified random sampling, dimana sampel diambil pada masing-masing strata yang ada.

\section{HASIL}

Tabel 1 menunjukkan bahwa sebagian besar (54.8\%) dari Responden memiliki tingkat pengetahuan kurang. Menunjukkan bahwa sebagian besar dari responden $(53.6 \%)$ siswi SMA Negeri 2 Kota Bengkulu memiliki sikap tidak mendukung atau unfavorable. Menunjukkan bahwa sebagian besar dari responden (52.4\%) siswi SMA Negeri 2 Kota Bengkulu memiliki tindakan yang baik tentang personal hygiene saat menstruasi.

Tabel 1 Gambaran tingkat pengetahuan, sikap dan tindakan remaja putri tentang personal hygiene saat menstruasi

\begin{tabular}{lcc}
\hline \multicolumn{1}{c}{ Variabel } & Frekuensi & Persentase (\%) \\
\hline Tingkat & & \\
Pengetahuan & & \\
Baik & 38 & 45,2 \\
Kurang & 46 & 54,8 \\
sikap & & \\
Unfavorabel & 45 & 53,6 \\
Favorabel & 39 & 46,4 \\
tindakan & & \\
Kurang & 40 & 47,6 \\
Baik & 44 & 52,4 \\
\hline
\end{tabular}

Tabel 2 Hasil Analisa Hubungan Tingkat Pengetahuan dan Sikap dengan tindakan personal hygiene saat menstruasi

\begin{tabular}{|c|c|c|c|c|c|c|}
\hline \multirow[t]{3}{*}{ Variabel } & $\begin{array}{r}\text { Tindaka } \\
\text { hygie } \\
\text { men }\end{array}$ & $\begin{array}{l}\text { personal } \\
\text { saat } \\
\text { uasi } \\
\end{array}$ & \multirow[t]{3}{*}{$\mathbf{F}$} & \multirow[t]{3}{*}{$\%$} & \multirow{3}{*}{$\begin{array}{c}\text { OR } \\
\text { (CI) }\end{array}$} & \multirow[t]{3}{*}{$\mathbf{P}$} \\
\hline & kurang & baik & & & & \\
\hline & $\%$ & $\%$ & & & & \\
\hline
\end{tabular}

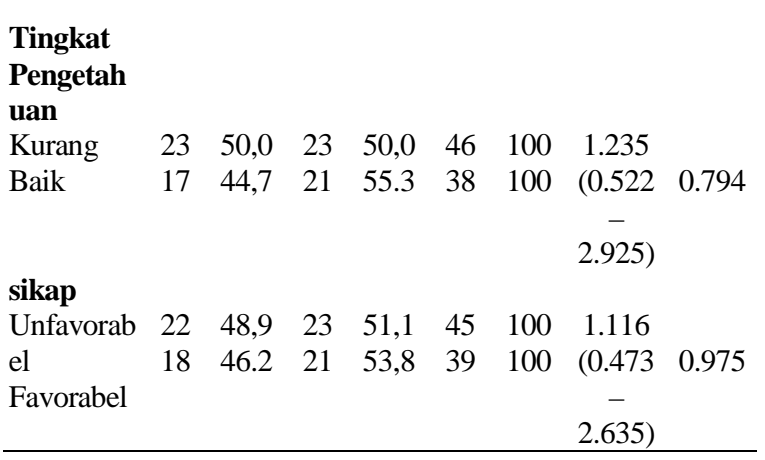

Tabel 2 menunjukkan bahwa hasil uji didapatkan $\mathrm{p}=0.794(\mathrm{p}>0.05)$ berarti tidak ada hubungan yang signifikan antara pengetahuan dengan tindakan personal hygiene saat menstruasi di SMA Negeri 2 Kota Bengkulu tahun 2014. Hasil uji didapatkan $\mathrm{p}=0.975(\mathrm{p}>0.05)$ berarti tidak ada hubungan yang signifikan antara sikap dengan tindakan personal hygiene saat menstruasi di SMA Negeri 2 Kota Bengkulu tahun 2014. 


\section{PEMBAHASAN}

Hasil uji didapatkan $\mathrm{p}=0.794(\mathrm{p}>0.05)$ berarti tidak ada hubungan yang signifikan antara pengetahuan dengan tindakan personal hygiene saat menstruasi di SMA Negeri 2 Kota Bengkulu tahun 2014. Hasil penelitian ini tidak sejalan dengan pendapat Notoadmodjo (2003) menjelaskan bahwa pengetahuan merupaka domain yang penting untuk terbentuknya tindakan seseorang. Sesuatu yang diketahuai berkenaaan dengan suatu hal atau objek lain. Pengetahuan tentang kesehatan sebagai parameter keadaan sosial sangat menentukan kesehatan masyarakat. Masyarakat depat terhindar dari penyakit asalkan pengetahuan tentang kesehatan dapat ditingkatkan sehingga perilaku dan keadaan sosialnya menjadi sehat.

Menurut pendapat Prasetyowati (2009) tindakan tidak menjaga kebersihan pada daerah kelamin saat menstruasi masih cukup tinggi hal ini disebabkan kurang mendapatkannya tentang cara bagaimana pentingnya menjaga kebersihan alat kelamin, mengganti pembalut dalam sehari, dan sedikitnya informasi yang diperoleh siswi tentang menstruasi. Menstruasi yang datangnya sangat awal akan menyebabkan munculnya beberapa tingkah laku patologis, pada umumnya mereka diliputi kecemasan-kecemasan berupa phobia. Gejala yang yang sering terjadi dan sangat mencolok pada haid pertama adalah kecemasan atau ketakutan diperkuat oleh keinginan untuk menolak proses fisologis tadi.

Hal ini dapat terjadi karena ada faktor predisposisi lain yang dapat mempengaruhi siswi memiliki tindakan personal hygiene yang baik saat menstruasi. Menurut Green dalam Notoadmodjo (2003) bahwa perilaku seseorang dalam memanfaatkan pelayanan kesehatan dipengaruhi oleh 3 faktor predisposisi mencakup pengetahuan, pendidikan, sikap masyarakat terhadap kesehatan, kepercayaan masyarakat terhadap hal-hal yang berkaitan dengan kesehatan dan status ekonomi.

Penelitian ini sejalan dengan penelitian yang dilakukan oleh Haryono (2010) menunjukkan bahwa 69 responden yang domain pendidikan SMA dan SMP memiliki pengeta- huan yang baik tentang personal hygiene saat menstruasi sebanyak 36 orang $(52,17 \%)$. Hal ini menunjukkan bahwa seba-gian besar responden memiliki pengetahuan yang baik mengenai kebersihan alat kelamin pada saat menstruasi.

Ada banyak sumber informasi tentang haid, misalnya dari guru sekolah, kalangan medis, bacaan dan film pendidikan. Bagi banyak orang tua, sumber-sumber informasi tersebut juga memberikan informasi yang berguna tentang proses terjadinya haid dan cara menjaga kebersihan selama menstruasi. Menstruasi yang datangnya sangat awal mengakibatkan anak kurang mendisiplinkan diri dalam hal kebersihan diri saat menstruasi. Padahal pengetahuan yang anak miliki tentang personal hygiene saat menstruasi dan akibatakibat tidak menjaga kebersihan diri saat menstruasi sudah baik serta kurangnya motivasi pada diri remaja putri dalam upaya peningkatan kesehatan untuk dirinya sendiri.

Sikap merupakan reaksi atau respon seseorang yang masih tertutup terhadap suatu stimulasi atau objek. Manifestasi sikap itu tidak dapat langsung dilihat, tetapi hanya dapat ditafsirkan terlebih dahulu dari perilaku yang tertutup. Sikap itu merupakan kesiapan atau kesediaan untuk bertindak dan bukan merupakan suatu tindakan aktivitas, akan tetapi adalah predisposisi tindakan suatu perilaku. Sikap mempunyai 3 komponen pokok yaitu kepercayaan (keyakinan), ide dan konsep terhadap suatu objek, kehidupan emosional atau evaluasi terhadap suatu objek, kecendrungan untuk bertindak (Notoadmodjo, 2003).

Penelitian ini sejalan dengan penelitian Susy (2005) yang meneliti tentang respon psikologis remaja putri menghadapi menarche menemukan bahwa $46,87 \%$ remaja putri bersikap menolak menarche. Begitu juga halnya penyuluhan tentang pendidikan seksual dan menarche kepada siswi yang kurang dari lingkungan sekitar seperti keluarga, guru.

Begitupun juga dengan penelitian Wibowo (2006) yang sejalan dengan penelitian ini dengan hasil remaja putri yang mempunyai sikap tidak mendukung (unfavorabel) tidak senang mendapatkan menarche 
yaitu 65 siswi $(51,24 \%)$. Hal ini dikarenakan perlunya dilakukan upaya dalam membentuk sikap yang mendukung tentang menstruasi yaitu dengan meningkatkan pengetahuan mereka tentang menstruasi.

Hasil penelitian ini menunjukkan bahwa lebih dari sebagian besar remaja putri mempunyai sikap tidak mendukung $(53,6 \%)$. Faktor predisposisi lain mungkin mempengaruhi kepercayaan (keyakinan), ide dan konsep terhadap suatu objek, kehidupan emosional atau evaluasi terhadap suatu objek, kecendrungan untuk bertindak.

Remaja putri pertama kali bersentuhan langsung dengan persoalan seksualitas pada saat ia mendapatkan menstruasi pertamanya, untuk itu pentingnya pendidikan seksual pada remaja putri adalah agar lebih mengenal tubuhnya. Bagaimana remaja putri memaknasi fungsi tubuh mereka dan menjaga tubuh mereka seperti menjaga kebersihan organ kewanitaannya.

\section{DAFTAR PUSTAKA}

Arikunto S. 2007. Manajemen Penelitian. PT. Rhineka Cipta. Jakarta

Azwar, S. 2011. Sikap Manusia Teori dan Pengukurannya. Yogyakarta: Pustaka Pelajar.

Badan Koordinasi Keluarga Berencana Nasional, 2003. Buku sumber Untuk Advokasi Keluarga Berencana, Kesehatan Reproduksi, Gender, dan Pembangunan Kependudukan, Jakarta: Badan Koordinai KB Nasional.

Budiarto, E. 2003. Metodelogi Penelitian Kedokteran. Penerbit Buku Kedokteran EGC, Jakarta.

Desmita, 2008. Psikologi Perkembangan. PT. Remaja Rosdakarya Offset. Bandung.

Harini, S. 2005. Jurnal Penelitian Poltekkes Surabaya. Surabaya.

Haryono. 2010. Jurnal Penelitian Poltekkes Samarinda. Samarinda.

Hidayat, 2009. Personal Hygiene. Diakses dari : http://hidayat2.wordpress.com pada tanggal 19 Oktober 2013.

Hurlock, E. 2004. Perkembangan Anak. Penerbit Erlangga. Jakarta.

Indriastuti, Putri, 2009. Hubungan Antara Pengetahuan Kesehatan Reproduksi dengan Perilaku Hygenis Remaja Puri Saat Menstruasi. Thesis, Universitas Muhammadiyah Surakarta.

Kingston, B. 1995. Mengatasi Nyeri Haid. Penerbit Arcan. Jakarta.

Dinkes Kota Bengkulu .2011. Proyeksi Dinas Kesehatan Kota Bengkulu 2011

\section{KESIMPULAN}

Berdasarkan hasil penelitian dan pembahasan sebagaimana telah diuraikan pada bab sebelumnya, maka dapat disimpulkan bahwa : Sebagian besar remaja putri SMA Negeri 2 Kota Bengkulu (54.8\%) memiliki Tingkat pengetahuan Kurang. Sebagian besar remaja putri SMA Negeri 2 Kota Bengkulu (53.6\%) memiliki sikap unfavorabel (tidak mendukung) Sebagian besar remaja putri SMA Negeri 2 Kota Bengkulu (52.4\%) memiliki tindakan personal hygiene saat menstruasi baik. Tidak ada hubungan secara signifikan antara tingkat pengetahuan dan tindakan personal hygiene saat menstruasi di SMA Negeri 2 Kota Bengkulu 2014 ( Nilai $p=0.794$ ). Tidak ada hubungan secara signifikan antara sikap dengan tindakan personal hygiene saat menstruasi di SMA Negeri 2 Kota Bengkulu 2014 ( Nilai $p=0.975$ ).

Manuba, IGB. 1999. Memahami Kesehatan Reproduksi Wanita. Penerbit Arcan. Jakarta.

Nazir, M. 1999. Metodelogi Penelitian. Penerbit Ghalia Indonesia. Jakarta.

Niven, N. 2002. Psikologi Kesehatan. Penerbit Buku kedokteran EGC. Jakarta.

Notoadmojo, S. 2007. Kesehatan Masyarakat. Rhineka Cipta. Jakarta.

. 2007. Metodelogi Penelitian Kesehatan. Rhineka Cipta. Jakarta.

Notoatmodjo. 2003.Pengantar pendidikan kesehatan dan ilmu prilaku kesehatan. Rhineka Cipta. Jakarta.

Prasetyowati, 2009. Jurnal Kesehatan Metro Sai Wawai. Lampung.

Progestian, Prima. 2009. Tolak Kanker, http://tolakkanker.blogspot.com , diakses pada tanggal 26 Oktober 2013.

Purnomo, A. 2010. Tips Merawat Alat Kelamin. Diakses dari: http://arispurnomo.com Pada Bulan 20 Oktober 2013.

Sarwono, 2006. Kebersihan Organ Reproduksi. Diakses dari: http://www.gizi.net. Pada tanggal 29 Oktober 2013.

Sarwono, SW. 2007. Psikologi Remaja. PT. Raja Grafindo. Jakarta.

SKRRI. 2004. Survei Kesehatan Reproduksi Remaja Republik Indonesia.http://balatbangbengkulu.files.wordpre ss.com Diakses 23 Oktober 2013 
170 Jurnal Media Kesehatan, Volume 9 Nomor 2, Oktober 2016, hlm 114-203

Soetjiningsih, 2004. Tumbuh Kembang Remaja. CV Sanggung Eto Jakarta.

Tarwoto. 2010. Anatomi dan Fisiologi Tubuh Manusia Untuk Mahasiswa Keperawatan. Jakarta: TIM.

Wibowo, 2006. Jurnal Kesehatan Poltekkes Surabaya. Surabaya.
Wiknjosastro, 2002. Ilmu Kebidanan Cetakan Ke VI. Yayasan Bina Pustaka. Jakarta.

, 2005. Ilmu Kebidanan. Jakarta : yayasan Bina Pustaka Sarwono Prawiharjo. 